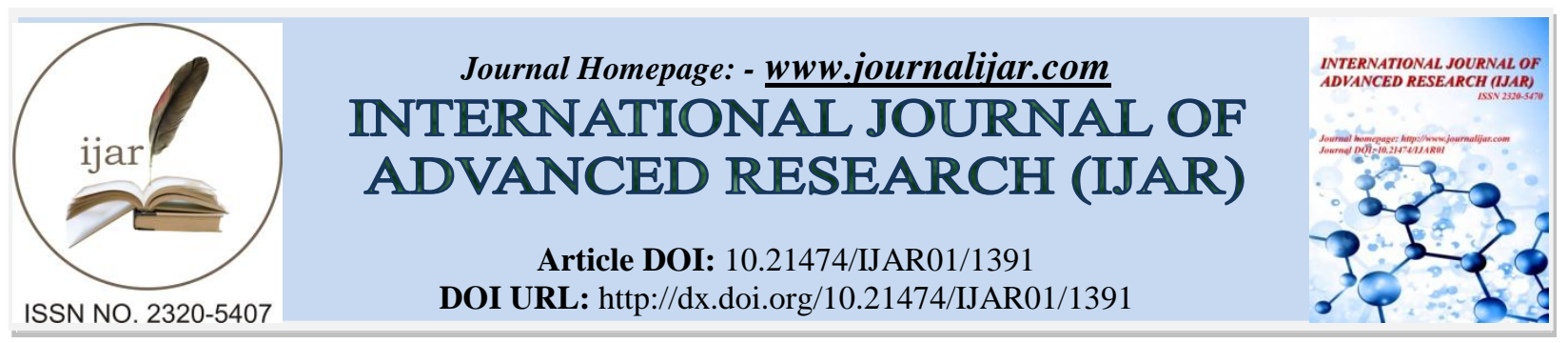

RESEARCH ARTICLE

SPECIAL CONCERN FOR DISABLED PERSONS UNDER THE INCOME TAX ACT IN INDIA.

Vidya V Devan.

Asst. Professor,Bharata Mata School of Legal Studies, Aluva.

Manuscript Info

Manuscript History

Received: 12 June 2016

Final Accepted: 19 July 2016

Published: August 2016

\section{Abstract}

Disability is not a curse. It is a phenomenon of the nature. They are also the part of the world. They should be brought to the frontline of the life. Not only social measures are sufficient to bring them up but also economical measures to support them and their family are essential. This article highlights the benefits which is provided by the government under The Income Tax Act in India, Professional Tax and a scheme to encourage private sector to provide employment opportunities to disabled.

Copy Right, IJAR, 2016,. All rights reserved.

"A true friend knows your weaknesses but shows you your strengths; feels your fears but fortifies your faith; sees your anxieties but frees your spirit; recognizes your disabilities but emphasizes your possibilities"

- William Arthur Ward

Differently abled is a euphemistic ${ }^{1}$ term for someone who might formerly have been classed as disabled, handicapped, challenged, or having special needs. It can apply to people with predominantly physical or mental challenges. The description is thought to be more politically correct in some circles because it recognizes that even if people have mental and/or physical impairments, they still have abilities, contrary to the picture painted with the terms disabled or handicapped.

The disabled or differently-abled persons defined under the Persons with Disabilities (Equal Opportunities, Protection of Rights and Full Participation) Act, 1995 (1 of 1996) as persons with disabilities, the severity of which is $40 \%$ and above are considered as special category of vulnerable persons.

\title{
Disabled persons:-
}

Corresponding Author:- Vidya V Devan.

Address:- Asst. Professor,Bharata Mata School of Legal Studies, Aluva.

\footnotetext{
${ }^{1}$ the substitution of a mild, indirect, or vague expression for one thoughtto be offensive, harsh, or blunt.

2 The Persons With Disabilities
} 
According to section 2 (i) "Disability" means

I) Blindness ${ }^{3}$

(ii) Low vision ${ }^{4}$

(iii) Leprosy-cured ${ }^{5}$

(iv) Hearing impairment ${ }^{6}$

(v) Loco motor disability ${ }^{7}$

(vi) Mental retardation ${ }^{8}$

(vii) Mental illness ${ }^{9}$

Differently-abled persons are facing enormous challenges and hardship in getting basic education, rehabilitation, continuous cost of medical requirements and getting employment or practicing a profession or vocation. The government of India has provided various concessions and reservations to empower disabled person and their families to give effect to the directive principle Article $41^{10}$ of the constitution.

(Equal Opportunities, Protection Of Rights And Full Participation) Act, 1995

3 2(b) "Blindness" refers to a condition where a person suffers from any of the following conditions, namely:-

(i) Total absence of sight. or

(ii) Visual acuity not exceeding 6160 or 201200 (snellen) in the better eye with correcting lenses; or

(iii) Limitation of the field of vision subtending an angle of 20 degree or worse;

${ }^{4}$ (u) "Person with low vision" means a person with impairment of visual functioning even after treatment or standard refractive correction but who uses or is potentially capable of using vision for the planning or execution of a task with appropriate assistive device;

${ }^{5}$ (n) "Leprosy cured person" means any person who has been cured of leprosy but is suffering from(i) Loss of sensation in hands or feet as well as loss of sensation and paresis in the eye and eye-lid but with no manifest deformity;

(ii) Manifest deformity and paresis; but having sufficient mobility in their hands and feet to enable them to engage in normal economic activity;

(iii) Extreme physical deformity as well as advanced age which prevents him from undertaking any gainful occupation, and the expression "leprosy cured" shall be construed accordingly;

${ }^{6}$ (1) "Hearing impairment" means loss of sixty decibels or more in the better year in the conversational range of' frequencies;

7 (o) "Loco motor disability" means disability of the bones, joints muscles leading to substantial restriction of the movement of the limbs or any form of cerebral palsy,

${ }^{8}$ (r) "Mental retardation" means a condition of arrested or incomplete development of mind of a person which is specially characterized by sub normality of intelligence;

${ }^{9}$ (q) "Mental illness" means any mental disorder other than mental retardation;

${ }^{10}$ Article 41. Right to work, to education and to public assistance in certain cases -The State shall, within the limits of its economic capacity and development, make effective provision for securing the right to work, to education and to public assistance in cases of unemployment, old age, sickness and disablement, and in other cases of undeserved want.

(n) "Leprosy cured person" means any person who has been cured of leprosy but is suffering from-

(i) Loss of sensation in hands or feet as well as loss of sensation and paresis in the eye and eye-lid but with no manifest deformity;

(ii) Manifest deformity and paresis; but having sufficient mobility in their hands and feet to enable them to engage in normal economic activity;

(iii) Extreme physical deformity as well as advanced age which prevents him from undertaking any 


\section{Concession in Tax:-}

Professor Seligman defines that tax is a compulsory contribution from a person to the government to defray the expense incurred in the common interest of all, without reference to special benefits conferred.

As tax is compulsory exaction. It cannot be avoided. But the income tax act 1961 provides many tax incentives and deduction to reduce the tax burden and to promote the welfare of the nation and the assesses. The tax laws in India is given in the Income Tax Act 1961

There are many disabled people and families who are paying tax and there are many individuals who have dependents who are disabled but are not aware of the provision of the various Acts which provides various benefits and concession in tax.

Income Tax benefits for the disabled persons are provided at two levels:

1. Directly - to the person with disability.

2. Indirectly - to the person who maintains the disabled dependant.

\section{Tax benefits Directly - To The Person With Disability:-}

Under section $80 \mathrm{U}^{11}$ of the income tax act 1961 while computing the total income of an individual in the previous year there shall be a deduction of fifty thousand rupees if he is certified by the medical authority ${ }^{12}$ as a person with disability. And if such individual is a person with severe disability the deduction is seventy-five thousand rupees. This $80 \mathrm{U}$ deduction will be available only to individual and who is a resident in India. The individual claiming a deduction under this section shall furnish a copy of the certificate issued by the medical authority.

Disability under $80 \mathrm{U}$ includes the persons mentioned in the clause $(i)$ of section 2 of the Persons with Disabilities (Equal Opportunities, Protection of Rights and Full Participation) Act, 1995 (1 of 1996), and includes "autism"13, "cerebral palsy ${ }^{14 "}$, and "multiple disabilities" ${ }^{15}$ referred to in section 2 of the National Trust for Welfare of Persons with Autism, Cerebral Palsy, Mental Retardation and Multiple Disabilities Act, 1999 (44 of 1999).

gainful occupation, and the expression "leprosy cured" shall be construed accordingly;

\section{${ }^{11}$ Deduction in case of a person with disability.}

80U. (1) In computing the total income of an individual, being a resident, who, at any time during the previous year, is certified by the medical authority to be a person with disability, there shall be allowed a deduction of a sum of fifty thousand rupees :

Provided that where such individual is a person with severe disability, the provisions of this sub-section shall have effect as if for the words "fifty thousand rupees", the words "seventy-five thousand rupees" had been substituted:

[Provided further that for the assessment years beginning on or after the 1st day of April, 2010, the provisions of the first proviso shall have effect as if for the words "seventy-five thousand rupees", the words "one lakh rupees" had been substituted.]

${ }^{12}$ (p) "Medical authority" means any hospital or institution specified for the purposes of this Act by notification by the appropriate Government;

${ }^{13} \mathrm{sec} 2$ (a) "autism" means a condition of uneven skill development primarily affecting the communication and social abilities of a person, marked by repetitive and ritualistic behaviour;

${ }^{14} \mathrm{Sec} 2$ (c) "cerebral palsy" means a group of non-progressive conditions of a person characterised by abnormal motor control and posture resulting from brain insult or injuries occurring in the pre- natal, peri-natal or infant period of development

${ }^{15} \mathrm{Sec} 2(\mathrm{~h})$ "Multiple Disabilities" means a combination of two or more disabilities as defined in clause (i) of section 2 of the Person with Disabilities (Equal Opportunities, Protection of Rights and Full Participation) Act, 1995 (1 of 1996) 
Person with disability means a person referred to in clause $(t)$ of section 2 of the Persons with Disabilities (Equal Opportunities, Protection of Rights and Full Participation) Act, 1995 (1 of 1996), or clause $(j)^{16}$ of section 2 of the National Trust for Welfare of Persons with Autism, Cerebral Palsy, Mental Retardation and Multiple Disabilities Act, 1999 (44 of 1999)

Person with severe disability means-

1. a person with eighty per cent or more of one or more disabilities, as referred to in sub-section (4) of section 56 of the Persons with Disabilities (Equal Opportunities, Protection of Rights and Full Participation) Act, 1995 (1 of 1996) or

2. a person with severe disability referred to in clause $(o)^{17}$ of section 2 of the National Trust for Welfare of Persons with Autism, Cerebral Palsy, Mental Retardation and Multiple Disabilities Act, 1999 (44 of 1999) i.e under the both act a person who suffers more than 80 percent of disability or who is suffering from more than one diability is termed as a person with severe disability . in the 2015 budget it was proposed to increase their deduction to one lakh twenty-five thousand rupees.

In B.Indrima v. Income Tax Officer ${ }^{18}$ it was considered that if the certificate issued by the concerned authority showed the disability of the person concerned as having considerably affected the capacity of the person to do normal work, it was very much liable to be acted upon by the departmental authority for providing the benefit of deduction. No other interpretation is possible because it is clearly stated in rule $11 \mathrm{D}^{19}$

\section{Transport Allowance. Section 10(14) Rule 2BB of Income Tax Act:-}

Transport allowance is granted to a salaried employee, to meet his expenditure for the purpose of commuting between the place of his residence and the place of his duty. The exemption is Rs 800/- Per month. But for employee, who is blind or orthopedically handicapped with disability of lower extremities, the exempted amount is Rs 1600/- Per Month. Tax Exempt is irrespective of actual expense.

${ }^{16}$ (j) "persons with disability" means a person suffering from any of the conditions relating to autism, cerebral palsy, mental retardation or a combination of any two or more of such conditions and includes a person suffering from severe multiple disability.

${ }^{17}$ (o) "severe disability" means disability with eighty percent or more of one or more multiple disabilities ${ }^{18}$ (2010)229CTR(Ker)377, [2009]184TAXMAN322(Ker)

19 11D. Permanent physical disabilities for the purposes of deduction under Section $\underline{80 \mathrm{U}}$ - For the purposes of Section 80U:

(i) permanent physical disability shall be regarded as permanent physical disability, it falls in any one of the categories specified below, namely:

(a) permanent physical disability of more than 50 per cent in one limb; or

(b) permanent physical disability of more than 60 per cent in two or more limbs; or

(c) permanent deafness with hearing impairment of 71 decibels and above; or

(d) permanent and total loss of voice.

(ii) mental retardation shall be regarded as a mental retardation if intelligence quotient is less than 50 on a test with a mean of 100 and a standard deviation of 15 such as the Wechsle scale.

(iii) blindness shall be regarded as a permanent physical disability, if it is incurable . 


\section{Tax Benefits To The Person Who Is Maintaining The Disabled Dependent:-}

In Past few years cost of medical treatment has shoot up very sharply and has made medical treatment almost out of reach of lower and middle class families in India. Government of India has in order to provide some relief to those who have a dependent with disability or sever disability provided some relief's from Income tax under section $80 \mathrm{DD}^{20}$ of the Income Tax Act, 1961.This deduction is available to Individual and Hindu undivided family, who is a resident in India. i.e it is not available to non-resident Indian (NRI).

- For individuals the dependents include

Spouse,

Son / daughter (any child), Parents and Brother / sister (siblings) can be your handicapped dependants. and your wife's or husband's brother or sister your parents' brother or sister. ${ }^{21}$

The Daughter of your mother's sister is, clearly, not coming under the definition of dependant for the purpose of claim of deduction u/s 80DD. So, you cannot claim deduction u/s. 80DD in respect of expenses incurred for her maintenance and medical treatment.

- For HUFs, any member of the HUF can be a disabled dependant.

The disabled person should be wholly or mainly dependant on you for his / her support and maintenance, and should not have claimed deduction under section $80 \mathrm{U}$. A person with disability means a person suffering from not less than $40 \%$ of any of the above disabilities. Severe disability means $80 \%$ or more of one or more of the above disabilities.

\section{Expenses are eligible for deduction:-}

- Expenditure for the medical treatment (including nursing)

- Training, and rehabilitation of a disabled dependent.

- Money paid to Life Insurance Corporation (LIC), Unit Trust of India or any other insurer for the purpose of buying specified scheme or insurance for the purpose of maintenance of such dependant.

\section{Amount of Deduction and Tax Saving:-}

- The deduction allowed is Rs. 50,000 if disabled dependant is suffering from disability.

Limit is raised to Rs. 75000/- from assessment year 2016-2017.

- Deduction allowed goes up to Rs. 1, 00,000 if disabled dependant is a person with severe disability. Limit is raised to Rs. 1,25000/- from assessment year 2016-2017

- Deduction not depend on amount of expenses incurred:- Even if your actual expenses on the disabled dependent relative is less then amount mentioned above, you will be eligible to full deduction.

${ }^{20}$ Deduction in respect of maintenance including medical treatment of a dependant who is a person with disability.80DD. (1) Where an assessee, being an individual or a Hindu undivided family, who is a resident in India, has, during the previous year,-

(a) incurred any expenditure for the medical treatment (including nursing), training and rehabilitation of a dependant, being a person with disability; or

(b) paid or deposited any amount under a scheme framed in this behalf by the Life Insurance Corporation or any other insurer or the Administrator or the specified company subject to the conditions specified in sub-section (2) and approved by the Board in this behalf for the maintenance of a dependant, being a person with disability,

the assessee shall, in accordance with and subject to the provisions of this section, be allowed a deduction of a sum of fifty thousand rupees from his gross total income in respect of the previous year:

Provided that where such dependant is a person with severe disability, the provisions of this sub-section shall have effect as if for the words "fifty thousand rupees", the words ${ }^{81}$ ["one hundred thousand rupees"] had been substituted.

21 : http://taxguru.in/income-tax/deduction-us-80dd-in-respect-of-expenses-incurred-on-maintenance-medicaltreatment-of-a-disabled-dependant.html\#sthash.WzPiHeMn.dpuf 
- The income tax that you can save would depend on the tax bracket that you fall into - it can range from Rs. 5,000 to Rs. 15,000 (for Rs. 50,000 deduction) or from Rs. 10,000 to Rs. 30,000 (for Rs. 1,00,000 deduction).

If the dependant, being a person with disability, predeceases the individual or the member of the Hindu undivided family an amount equal to the amount paid or deposited according to this section shall be deemed to be the income of the assessee of the previous year in which such amount is received by the assessee and shall accordingly be chargeable to tax as the income of that previous year.

The physical and mental agony experienced by the parents/ guardian of such dependants cannot be taken away. But Government of India, National Trust, LIC and other charitable institutions are doing commendable job by reducing the financial agony of such families. These benefits must be made aware of to the people who are in need. This is a bit of social work which can give relief to handicapped persons and their parents.

\section{Clubbing provision applicable to disabled persons Section 64 (1A)}

Normally, a person is taxed in respect of income earned by him only. But when the person tries to avoid their tax liability by transferring their assets to their family members such as spouse and children, income of other person is included (i.e. clubbed) in the taxable income of the taxpayer and in such a case he will be liable to pay tax in respect of his income (if any) as well as income of other person too. The situation in which income of other person is included in the income of the taxpayer is called as clubbing of income. E.g., Income of minor child is clubbed with the income of his/her parent. Sections 60 to 64 give various provisions relating to clubbing of income $^{22}$. The effect of clubbing is that the person who attempts to reduce his income from his calculations and then including it in to the spouse will not be able to do that. The amount shall be included in the tax liability of the holder itself and his total effort to avoid tax or reduce the amount would not be possible. ${ }^{23}$

According to section 64 income of individual will include income of minor child. But section $64(1 \mathrm{~A})^{24}$ specifically exclude the clubbing of income of a minor child who is suffering from any disability of the nature specified in section $80 \mathrm{U}$.

As the income of the child is not clubbed the child is treated as a separate entity and can file an independent return with all its benefits. In effect the Individual can transfer their revenue generating asset like fix deposits in the name of disable child and the interest earned will not be clubbed with the income of individual but will be assessed separately, which provides significant scope for tax savings. Further the disable child while filing its own return can claim benefit under section $80 \mathrm{U}^{25}$

\section{Suggestions:-}

Though the government is providing some relief in tax, much can be done for the empowerment of the disabled. Considering rising cost of living and increasing cost of medicine supplies and rehabilitation, the exemption under $80 \mathrm{U}$ and deduction for expenditure incurred for medical treatment under 80DD should be increased to Rs. 2,00,000/, One of the major problem which the person with disability faces is in travelling, most of them spend huge amount on commuting to work places as public mode of transport is not accessible for wheelchair users and for most other users, considering this government should increase the limit of transport allowance exemption for salaried class up to Rs. 4000/- Pm. Following the Maharashtra Rules, the Professional Tax for the disabled has to be exempted throughout the nation.

${ }^{22} \mathrm{http}$ ///taxguru.in/income-tax/clubbing-of-income-under-the-income-tax-act-1961.html\#sthash.HHLcU8No.dpuf

${ }^{23}$ http://www.itrtoday.com/tag/clubbing-of-income/

${ }^{24} 64$ (1A) In computing the total income of any individual, there shall be included all such income as arises or accrues to his minor child, not being a minor child suffering from any disability of the nature specified in section $80 \mathrm{U}$ :

${ }^{25}$ CA. Chirag Chauhan is member (Membership Number 131194) of the Institute of Chartered Accountant of India. 


\section{Conclusion:-}

To support the disabled community, not only the efforts from the government are required but there should be willingness from the corporate world, to provide them equal opportunity and level playing field. Most of the corporate offices are not accessible to the person who is on wheelchair. However slowly the environment is changing and corporate have realised that providing employment is not just part of CSR but the differently -abled people are itself great resource which can contribute equally for the objectives and goals of the organization and society at a large. And the income earned by these persons after overcoming all the difficulties are taxed. We have to think about completely exempting these persons from the purview of tax. 